\title{
水素化アモルファスシリコン薄膜内部の 構造不均質性の評価法
}

$\begin{array}{lllll}\text { 正 員 本 } & \text { 間 } & \text { 和 } & \text { 明電機大) } \\ \text { 正 員 本 } & \text { 橋 } \text { 光 也 (電機大) } \\ \text { 非会員 安 達 久 } & \text { 久美 (電機大) }\end{array}$

Characterization of Structural Inhomogeneities in Hydrogenated Amorphous Silicon Films

Kazuaki Homma, Member, Mitsuya Motohashi, Member, Kumi Adachi, Non-member (Tokyo Denki University)

キーワード: 水素化アモルファスシりコン薄膜, 構造不均䁈性, 微結晶化温度, 水素放出特性

グロー放電法によって作製した水素化アモルファス シリコン膜（ $a-\mathrm{Si}: \mathrm{H}$ 膜）は, 膜厚方向に構造不均 質性を生じやすいことが指摘されている(1)(2)。a-Si： $\mathrm{H}$ 膜の電子デバイスへの応用と，その高性能化に際 しては, この膜構造の不均質状態を測定し，その均質 化を図ることが極めて重要である。従来, 膜中の不純 物分布の測定に関しては多くの報告があるが，場所的 な構造不均買性の評価に関する報告注少ない。

本報告は， $a-\mathrm{Si} ： \mathrm{H}$ 膜内を拡散によって通過する 水素量が, 加熱による膜の微結晶化に依存して大きく 変化することに着目し，微結晶化温度範囲における水 絜の膜通過量の温度依存性から, 膜内部の場所的構造 不均質性を評価する方法を提案した。

図1は実験素子の原理的な構造を示している。この 素子では，基板と $a-\mathrm{Si}: \mathrm{H}$ 膜界面に $a-\mathrm{Si}: \mathrm{H}$ 膜に比 べて高濃度の水素を含む領域を設けてあり，加熱によ ってこの領域の水素を $a-\mathrm{Si}: \mathrm{H}$ 膜を通して真空中に 放出させる構造となっている。このとき，膜中の水素 の拡散が, 膜からの水素の放出速度 $J_{H}$ を律速してい るため,

$$
\begin{aligned}
& J_{H}=-D(d N / d x) \cdots . . \\
& D=D_{0} \exp \left(-\frac{\Delta E}{k T}\right)
\end{aligned}
$$

ここで, $N:$ 膜中の水素濃度, $D:$ 水素の拡 散係数, $D_{0}$ : 定数, $\Delta E:$ 活性化エネルギー, $T:$ 温度, $k:$ ボルッマン定数 で表される ${ }^{(3)}$ 。更に，水素の拡散においてはFickの

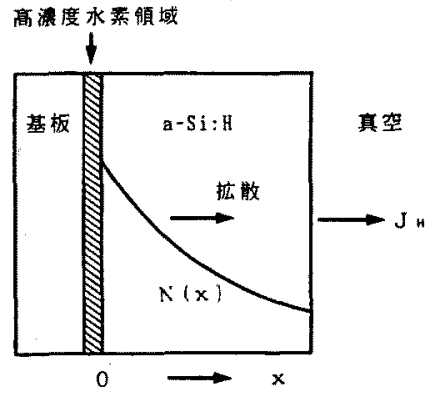

図 1 実験素子の構造

Fig. 1. Structure of experimental device.

法則が成立するものとしてある。

拡散係数 $D$ は膜の微結晶化温度によって変化し, これに依存して水素放出速度 $J_{H}$ が変化する。このと き, 微結晶化は狭い温度範囲で起こる。従って, 膜構 造が場所的に不均質でありこれれに対応して微結晶化 温度が場所的に異なっているときは, 膜を一定昇温速 度で加熱して微結晶化させ，そのときの $J_{H}$ の測定に よって, 微結晶化温度の場所的分布に関する情報が得 られる。このとき， $J_{H}$ の温度に対する変化率 $\delta=$ $-\beta\left(d J_{H} / d T\right)$ を用いる方法が便利である。ここで， $\beta$ は, 剆定系の感度と膜厚, 膜面積などによって決まる 定数である。

結局, 微結晶化温度は加熱前の膜構造に関する情報 を有していることから ${ }^{(4)}, \delta の$ 測定により，膜構造の 場所的不均質性を評価することができる。

笔学諭A, 110 巻 9 号, 平成 2 年 


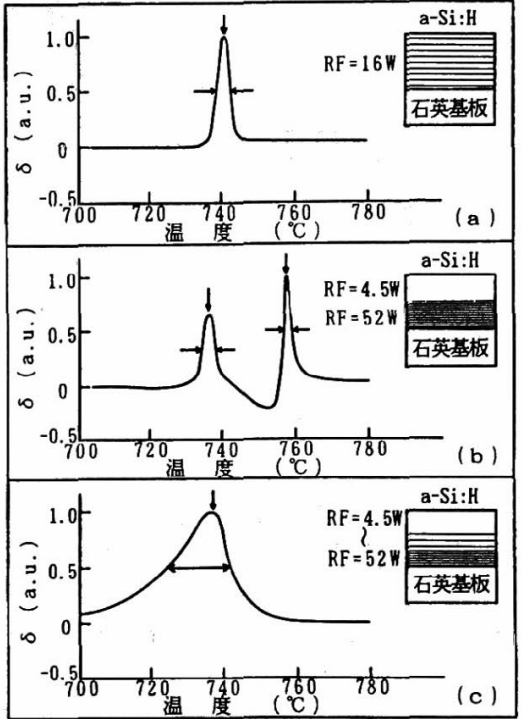

図 2 膜構造と $\delta$ の関係

Fig. 2. Relation between film structures and $\delta$.

図 2 は, $a-\mathrm{Si}: \mathrm{H} / \mathrm{SiO}_{2}$ 基板界面に存在する結合水 素を利用し(2)，上記方法によって $a-\mathrm{Si}: \mathrm{H}$ 膜内部の 不均質状態を測定した例である。水素放出の測定は四 重極質量分析計を用いて行った。(a ) 図は膜作製時の 高周波電力 $(R F)$ 一定, ( $\mathrm{b})$ 図は途中で高周波電力を 急激に変化，また $(\mathrm{c})$ 図は高周波電力を時間に対して 連続的に変化させて作製した $a-\mathrm{Si}: \mathrm{H}$ 膜の $\delta$ の測定 結果である。(a)図のように均質構造膜に対しては半 值幅の狭い $\delta$ のが一個現れ, (b)図のように 2 層 構造膜に対しては $\delta$ のが 2 個現れている。また, (c)図の $\delta$ は膜構造が内部で連続的に変化している ことを反映し，半值幅の広い山となって現れている。 以上, 高周波電力を変えて作製した素子内部の構造不 均質性を本方法によって検討した結果, 的確に推定で きることがわかった。なお， $\delta$ と構造不均質性間のよ り詳細な比較は, 水素の拡散方程式と $J_{H}$ の測定値を 用いたコンピュータシミュレーションにより得ら れる。

(平成 2 年 5 月 25 日受付)

\section{文献}

(1) H. Fritzsche: "Heterogeneities and surface effects in glow discharge deposited hydrogenated amorphous silicon films.", Thin Solid Films. 90, 119 (1982)

（2）本橋・本間・深海：「グロー放電法により作製した水素化ア モルファスシリコン薄膜の基板依存性」, 電学諭 $\mathrm{A}, 109$, 327 (平元-8)

(3) B. Tuck : Introduction to diffusion in semiconductors (1974) Peter Peregrinus Ltd., England.

（4）本橋・本間・深海：「グロー放電水素化アモルファスシリコ ン膜に及ほすプラスマ制御用電極の影響」, 信学論, J72CII, 1082 (平元-12)

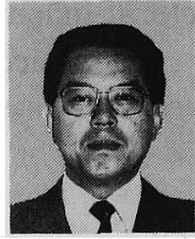

本 間 和 明（正員）

昭和 41 東京電機大学大学院博士 課程修了。同大学助手, 講師, 助教 授を経て, 現在, 同応用理化学科教 授。工学博士。深い不純物準位を有 する半導体，およびアモルファス半導体薄膜の物性と デバイスの研究・開発に従事。電子情報通信学会, 応 用物理学会会員。

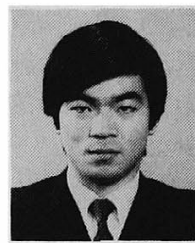

本 橋 光 也 (正員)

昭和 63 年東京電機大学大学院修 士課程修了。現在, 同博士課程在学 中。シリコン系アモルファス薄膜の 物性とデバイスの研究・開発に従事。 電子情報通信学会, 応用物理学会会員。

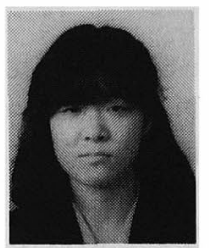

\section{安 達 久美 (非会員)}

平成元年東京電機大学工学部応用 理化学科卒業。現在, 同大学院修士 課程在学中。シリコン系アモルファ ス薄膜の物性とデバイスの研究・開 発に従事。応用物理学会会員。 